circuits. In many parts of the world, the cable systems have been reorganized. The terminals of certain radio circuits in South Africa, India, Canada, Egypt and Australia are operated by local companies.

The Post Office also maintains a broadcast telegraph service on long and short wave-lengths. Radiotelephony in the United Kingdom is con. trolled and operated by the G.P.O., but the overseas terminals in the Dominions are controlled by the local companies or by the operating company. The operating company also handles abroad the shore end of various ship services, some of which are fitted with direction-finding apparatus. At Nairobi, Bermuda and Bahrain, Adcock direction-finding stations for air services are in operation. There are radio-phototelegraph services with New York, Buenos Aires, Melbourne and Tokio ; also land telephony in Cyprus and Peru, and broadcasting in Kenya. The present telegraph system comprises 155,090 nautical miles of submarine cable, 125 wireless circuits, and 161 overseas branches. The tables given show that nearly all the Empire routes from the United Kingdom are served both by cable and by wireless. London stands out clearly as the focal point of the whole system.

During certain periods of the day, much of the traffic between distant parts of the Empire passes through London. For example, South Africa-India traffic may travel via the Cape Town-London beam and the London-Bombay, or via the cable chains over the same route. Many alternative routes to Australia are given. The choice as between wireless and cable is primarily dependent on the senders' instructions; but the particular route is regulated in part by the out-payments that have to be made on the various routes. These depend very largely on the time of traffic flow, and this, again, is largely dependent upon the business times in various parts of the world. During the night on a route which is served both by wireless and by cable, the cable circuit may carry the bulk of the traffic, since the majority of the cable chain stations may have to be kept fully manual to serve other routes; methods have now been devised which largely overcome the effects of 'fading' and 'atmospherics'. Verdan working, while largely eliminating fades and atmospheries, fails when both these factors are present at the same time. Considerable experimental work is still being carried out, but only with limited success.

The author also considers the effect of cosmic conditions on wireless telegraph circuits, and explains how in practice large use is made of the effects of the solar cycle when predicting future conditions. The optimum wave-lengths of transmission for any given route are dependent upon the season and the time of the day and-this is an important factor-the degree of solar activity, which is found to follow approximately an $11 \frac{1}{2}$ years' cycle. The last sunspot maximum period was during 1928-29, and the minimum period during 1933-34. The years following the latter period have been accompanied by a marked increase in activity, which on a half-yearly basis exhibited a well-defined peak for January-June 1937. Records for the past hundred years reveal that, whilst the average length of cycle is $11 \cdot 4$ years, the change from minimum to maximum activity occurred over an average period of only 4.5 years; a study of wireless data for the year 1938 indicates that it is not improbable that the year 1937 may prove to have been the maximum peak of the present cycle. Unlike long-wave transmission, it is found that increased solar activity, with its increase in ionization, enhances the utility of the shorter wave-lengths.

At certain times and seasons, the attenuation of wireless signals is so low over both the major and minor ares of the great circle embracing the two terminals that signals may arrive both by the forward and the backward route, and even encircle the globe some two or three times. Diagrams are given showing the reception at the P.O. station at Bridgwater of two consecutive dots transmitted from Cape Town together with a sequence of three 'echoes' of the main transmission, as the result of the rays encircling the globe three times.

\title{
The Gorge Dam, Hong Kong
}

\begin{abstract}
THE problem of providing adequate water storage to meet the needs of the population of Hong Kong is a peculiarly difficult one by reason of the relatively large population living in a small mountainous area in which the rainfall is confined to the monsoon period of about six months. Although provided with twelve reservoirs with a gross capacity of 3,000 million gallons, there were only seven years since 1921 during which an unrestricted supply of water could be given. Faced with the necessity of obtaining further supplies, the director of public works, Mr. R. M. Henderson, came to the conclusion that the best solution lay in constructing a reservoir which should impound the waters of the Shing Mun - a river situated in an area on the mainland, leased from the Chinese Government in 1898 for a period of ninety-nine years and known as the 'leased territory'.
\end{abstract}

The scheme, as finally developed, provided for the construction of a reservoir having a capacity equal to the combined capacities of the existing reservoirs, thus doubling the provision for the Colony. To give effect to this plan it was necessary to build several dams and, of these, the largest-the Gorge Dampresents both in its design and in its construction several features of especial interest. These were described in a paper read before the Institution of Civil Engineers by W. J. E. Binnie and H. J.F. Gourley on January 24.

The design selected as most suitable for the purpose and place was based on two principal considerations-oconomy in construction and the elimination of eracks such as would allow of the penetration of water and might arise from earth tremors or from volumetric changes due to the thermal phenomena exhibited in large masses of setting concrete.

The dam has a height of $275 \mathrm{ft}$. above the streambed and its length at the top is $690 \mathrm{ft}$. Its main structure, the 'thrust block', is not the actual dam but, in conjunction with the 'rock-fill' and the 'sand wedge', acts as a support for the 'diaphragm' or screen which forms the barrier to the water 
This thrust block transmits the water pressure to the rock-fill and presents to the diaphragm a row of buttresses faced with pre-cast concrete blocks. Against these blocks leans the diaphragm, which forms the main water face and is an articulated structure composed of vertical panels $25 \mathrm{ft}$. in width. Each panel was made in 'lifts' of $20 \mathrm{ft}$. at one operation and is reinforced with a 'grille' of steel rods $1 \frac{1}{4}$ in. in diameter.

Every precaution was taken to ensure water tightness, and when the reservoir was filled to top waterlevel there was no leakage whatever. The spaces between the buttresses, the centres of which are $12 \frac{1}{2} \mathrm{ft}$. apart, and the function of which is to support the diaphragm, constitute inspection pits whereby the diaphragm can be examined. Access is obtained to these pits by branch galleries connected with the main galleries, which are reached by steps from both ends of the dam. These pits would also, in emergency, act as interceptors of any water leaking from the reservoir and so prevent it entering and disturbing the sand wedge. It will be apparent that the design adopted has produced a structure possessing considerable flexibility so that disturbances might take place without giving rise to more than minor and controllable cracking. The details by which this result is obtained are described and illustrated in the paper.

\section{River Physics in India}

$\mathrm{O}^{\mathrm{N}}$ NE of the major problems of India is that of the rivers, and it was with the object of inviting the attention of the central and provincial Governments to the urgency of making investigations on scientific lines that a symposium was organized by the National Institute of Sciences of India a little more than a year ago. The several papers presented have now been published (Proc. Nat. Inst. Sci. India, 4, No. 4) and show the profound interest that is being taken in the subject by a number of wellqualified workers. The presidential address by Prof. M. N. Saha pointed out the importance of the rivers to the agricultural life and as a means of the indus. trialization of India, and dealt with their influence on the level of cities on their banks, instancing the destruction of many ancient cities and the increasing difficulty now being experienced in the drainage of Calcutta by reason of this action (see also NATURE, 141, 797 ; 1938).

"The Post-Tertiary Hydrography of Northern India and the Changes in the Courses of the Rivers during the last Geological Epoch" were dealt with in a paper by D. M. Wadia, in which he traced the tectonic movements which have caused widespread and radical alterations in the whole system of drainage lines. The number, volume and direction of the units of this system bear evidence of changes which in some instances have amounted to the complete re. versal of the flow of such a principal river as the Ganges. In a paper on the "Changes in the Drainage of India as evidenced by the Distribution of Freshwater Fishes", Dr. S. L. Hora adduced evidence from various sources to show that there was a reversal of the drainage in the post-trappean period. From the nature of the valleys of the rivers and from certain other features of the physiography of the peninsula, it is concluded that the present-day lower portions of the rivers are of great antiquity, whereas the upper reaches are comparatively recent.

Coming more closely into touch with the nature of the problem of the present day, one of the difficulties facing the engineer is the construction of works in an alluvial boulder river bed, and the problems in respect of river training thereby presented have yet to be solved. Associated with these is the need for constructing irrigation canals transporting alluvium from the river on such lines as should ensure a condition of working stability and tend neither to silt nor to scour. This aspect is dealt with in a paper, "Flow of Water in Alluvial Channels", by G. Lacey, in which he directs attention to those elementary principles which help to clarify issues and restrict generalization in river physics. He submits the view that despite the complexity of the problem presented by the great Indian rivers, the basic equations are of a simple nature and that it is on the foundation of the 'normal' or 'regime' channel flowing with constant discharge and silt charge that our ultimate knowledge of river physics must be based.

In his address on "The Use of Models for Elucidating Flow Problems based on Experience gained in carrying out Model Experiments at the Hydrodynamic Research Station, Poona", C. C. Inglis described several types of models and explained why some present little difficulty and yield results suitable for immediate application. Other types, especially those relating to alluvial rivers, present great practical difficulties, and in these cases, the data available are usually too meagre. In so many instances the problems presented are too urgent, requiring immediate steps to arrest the damage that is taking place. The magnitude of this class of problem is shown by the statement that during two years the cost of repairs to the Hardinge Bridge over the Ganges amounted to nearly a million pounds. Such questions require an intimate knowledge of the engineering side of the matter combined with a flair for diagnosis and a capacity to visualize a remedy.

It is the silt carried down by the floods which is at the root of much of the trouble. It has created the land, and made it habitable ; it has also fertilized it and made it prosperous. But, as is shown in S. C. Majumdar's paper, "River Problems in Bengal", it has also, by damaging the river channels, caused their diversion through lower aruas, leaving the other to become derelict. By raising the beds and consequently the flood level, the silt has created another set of problems, and it is the silt which has destroyed many of the tidal rivers in Central Bengal and is threatening also the cross channels so valuable to navigation. The concluding paper by Dr. N. K. Bose, entitled "River Physics Laboratories of Europe and America", deals briefly with what is being done on these lines elsewhere, but ultimately it must prove that the solution of the problems of India must be found by long and concentrated study of local conditions. 